\title{
Scanning electron microscopy of rheumatoid arthritis peripheral blood polymorphonuclear leucocytes
}

\author{
D A McCARThY, ${ }^{1}$ C M HOLBURN, ${ }^{1}$ B K PELL, ${ }^{1}$ S R MOORE, A P KIRK, ${ }^{2}$ \\ AND J D PERRY \\ From the ${ }^{1}$ School of Biological Sciences, Queen Mary College, Mile End Road, London; and the \\ ${ }^{2}$ Rheumatology Department, The London Hospital, Whitechapel, London
}

SUMMARY Peripheral blood polymorphonuclear leucocytes (PMNs) were isolated from six normal individuals and from 27 patients with rheumatoid arthritis (RA) by the Ficoll-Hypaque rapid single step centrifugation technique, fixed in suspension, and examined by scanning electron microscopy (SEM). In addition, four of the preparations from normal individuals and eight from patients with RA were examined by transmission electron microscopy (TEM). Most PMNs in preparations from normal subjects were spherical, unpolarised, and had their surface membrane elaborated into irregular ridges and small ruffles; they contained few phagocytic vacuoles and large numbers of electron dense primary and secondary granules. A minority of the cells were non-spherical, polarised, and had portions of their surface membrane elaborated into ruffled pseudopodia. In contrast, preparations of RA PMNs frequently contained fewer unpolarised PMNs and a higher number of polarised PMNs than did preparations of normal PMNs. Some preparations of RA PMNs also contained substantial numbers of spherical cells whose surface was covered mainly by bulges and blebs. Concurrent examination by TEM showed that RA PMNs frequently contained more phagocytic vacuoles and fewer electron dense primary and secondary granules than normal PMNs. The morphological and ultrastructural changes seen in RA PMNs resembled those which normal PMNs are known to undergo on exposure to C5a in vitro, during adherence to endothelial cells in vivo, or during phagocytosis in vivo or in vitro. Our observations, therefore, provide a useful morphological correlation to those in vitro studies in which differences in the functional activity of RA and normal PMNs have been shown. The possibility that the difference seen between RA and normal PMNs is artefactual and does not represent the genuine in vivo states of these cells is discussed.

Key words: haematology, inflammation, phagocytosis, neutrophil morphology, ultrastructure.

Observations that patients with rheumatoid arthritis (RA) or Felty's syndrome suffer an increased morbidity and mortality from pyogenic infections ${ }^{1}$ and the knowledge that polymorphonuclear leucocytes (PMNs) are important in the defence against bacterial infections ${ }^{2}$ prompted many researchers to test the hypothesis that PMN function in these patients might be impaired. As a result the activity of peripheral blood PMNs from patients with RA and patients with Felty's syndrome has been

Accepted for publication 23 April 1986.

Correspondence to Dr D A McCarthy, School of Biological Sciences, Queen Mary College, Mile End Road, London E1 4NS. examined by various in vitro functional assay procedures. The results of these studies are not wholly concordant. Briefly, some investigators have reported that RA peripheral blood PMNs show altered activity when compared with normal PMNs in assays of chemotaxis, ${ }^{3}$ phagocytosis, ${ }^{4}$ bacterial killing, ${ }^{5}$ and oxidative metabolism,${ }^{6}$ while others have found no differences. ${ }^{7-10}$ Alterations in activity have been attributed to the prior ingestion of immune complexes by RA PMNs, because in several studies normal PMNs were found to undergo similar changes if incubated with heat aggregated IgG or with RA sera before assay. Furthermore, 
immunoglobulin inclusions, perhaps representing phagocytosed immune complexes, have been found in RA blood PMNs, by some, ${ }^{11}$ though not by all investigators. ${ }^{12} \mathrm{By}$ way of contrast, there is little dispute, at least as yet, that increases occur in the proportion of PMNs possessing a low surface charge $^{13}$ or expressing C3R receptors, ${ }^{14}$ that decreases occur in the proportion of cells expressing Fc receptors, ${ }^{11}$ and that the polypeptide composition of the plasma membrane is altered..$^{15}$ Other in vitro studies with normal PMNs have shown that degranulating stimuli and various chemoattractants can decrease the surface charge, ${ }^{16}$ increase adhesiveness, ${ }^{17}$ induce cell-cell aggregation, and cause morphological changes in the plasma membrane. ${ }^{18}{ }^{19}$ Thus taken altogether, these reports suggest that the surface properties of RA peripheral blood PMNs may differ from those of normal PMNs, perhaps as a consequence of prior activation in vivo. We thought it worthwhile, therefore, to examine the surface morphology of RA peripheral blood PMNs by means of scanning electron microscopy (SEM) and now report our results in this paper.

\section{Patients and methods}

\section{PATIENTS}

Twenty eight patients with RA were selected at random from among those attending outpatient clinics at The London Hospital (Whitechapel) or from inpatients at The London Hospital (Mile End). Twenty four were seropositive for rheumatoid factor and all satisfied the American Rheumatism Association criteria for 'classical' or 'definite' disease. One patient was taking no drugs whatsoever, all others were taking non-steroidal anti-inflammatory drugs (NSAIDs): two patients were taking steroids, seven were taking penicillamine, two were receiving gold, one was taking both penicillamine and steroids, another was taking cyclophosphamide and steroids, and five were taking azathioprine in addition to the NSAIDs. A clinical assessment of disease activity was made when the blood was drawn. Normal healthy hospital or college staff acted as control subjects.

\section{PMN PURIFICATION}

Specimens of venous blood $(10 \mathrm{ml})$ were drawn between 10.00 am and midday from a non-occluded vein in the antecubital fossa. They were mixed with preservative free heparin (Weddel Pharmaceuticals Ltd, London, UK; final concentration $10 \mathrm{U} / \mathrm{ml}$ ) in a polycarbonate tube, kept at $25-37^{\circ} \mathrm{C}$ and inverted every two to three minutes until the PMNs were purified a maximum of $15 \mathrm{~min}$ later by the rapid single step Ficoll-Hypaque centrifugation procedure. ${ }^{20}$ PMNs were isolated from the normal bloods by centrifuging over Ficoll-Hypaque solutions $(\varrho=1.114 \mathrm{~g} / \mathrm{ml})$ comprising $6 \%$ or $7 \%$ Ficoll 400 (Pharmacia Ltd; Milton Keynes, UK) with sodium diatrizoate and meglumine diatrizoate in a ratio of 3.33 : 6.66 (medium 1). ${ }^{20}$ Because the components of most RA bloods do not separate satisfactorily when centrifuged over this medium, RA bloods were centrifuged on a few occasions over solutions containing $7 \%$ Ficoll with sodium diatrizoate and meglumine diatrizoate in a ratio $7.5: 2.0$ (medium $2),{ }^{21}$ but mostly solutions $(\varrho=1 \cdot 114 \mathrm{~g} / \mathrm{ml})$ comprising $5 \%$ or $6 \%$ Ficoll with sodium diatrizoate but no meglumine diatrizoate (medium 3 ) were used. ${ }^{22}$ The lower (PMN containing) leucocyte band was removed and diluted to $10 \mathrm{ml}$ with Eagle's minimal essential medium containing Earle's salts (Gibco Bio-cult; Glasgow, Scotland) and $20 \mathrm{mM}$ HEPES (N-2-hydroxyethylpiperazine- $\mathrm{N}^{\prime}$-2-ethanesulphonic acid) buffer $\mathrm{pH} 7.3$ (MEM), to which $2.5 \mathrm{U} / \mathrm{ml}$ of preservative free heparin was added shortly before use. The PMNs were collected by low speed centrifugation and washed by centrifuging twice more with the same volume of MEM. It was noticeable that on occasion a proportion, perhaps $5-20 \%$ of the PMNs in a sample, aggregated into small clumps approximately $0.5-2.0 \mathrm{~mm}$ in diameter at the interface between the Ficoll-Hypaque and plasma. This happened rarely with normal bloods but frequently with RA bloods, irrespective of the composition of the Ficoll-Hypaque medium. The aggregates were readily dispersed when first resuspended, but the RA PMNs had a marked tendency to aggregate again during subsequent centrifugation steps. Attemps were made to minimise the extent of aggregation by: (a) including heparin in the first washing solution, $(b)$ keeping PMNs in suspension at low cell densities (less than $10^{6} / \mathrm{ml}$ ), (c) frequently inverting the tubes in which the PMNs were contained, $(d)$ centrifuging cells through short column heights for the shortest times (two to three minutes) and at low speeds (1300-1500 rev/min) consistent with obtaining a good recovery, and $(e)$ resuspending cell pellets as soon as the centrifuge had stopped. PMNs ceased aggregating once they had been fixed with glutaraldehyde (see below). Aggregated cells were sometimes removed by filtering through Miracloth (Calbiochem Ltd, San Diego, California, USA) either just before or immediately after fixation, but this was not done routinely (see text).

The purity of PMN preparations was checked by phase contrast light microscopy or after staining with May-Grünwald Giemsa stain. Although prep- 
arations of RA PMNs were sometimes contaminated by erythrocytes and platelets, very few $(<5 \%)$ mononuclear cells were present.

In order to investigate whether the purification protocol might affect the morphology of PMNs as seen subsequently by SEM the following experiments were done. PMNs were purified simultaneously from normal blood samples by centrifugation over Ficoll-Hypaque media 1 and 3 , and by isopycnic centrifugation in a Percoll density gradient. ${ }^{23}$ In addition, the PMNs from an RA blood were purified simultaneously by centrifugation over Ficoll-Hypaque (medium 3) and by isopycnic binding in Percoll. No significant differences were observed between PMN preparations made from the same blood sample by these different procedures (results not shown). Synovial fluids free of blood were drawn aseptically without the use of any anaesthetic agents from the knee joints of patients with RA for therapeutic reasons. They were treated with hyaluronidase $(75 \mathrm{IU} / \mathrm{ml}$; Fisons $\mathrm{Ltd}$, Loughborough, England) for $15 \mathrm{~min}$ at $37^{\circ} \mathrm{C}$ and the PMNs purified by centrifugation over FicollHypaque medium 2 as described above.

\section{ELECTRON MICROS COPY}

Cells were fixed in suspension by a glutaraldehydeosmium tetroxide-tannic acid-uranyl acetate procedure and examined by electron microscopy largely as described previously. ${ }^{24}$ On some occasions PMNs to be examined by SEM were trapped on poly/Llysine (mol. wt 70 000-150 000; Sigma Chemical Co. Ltd, Poole, Dorset, UK) coated coverslips, but mostly they were collected on polycarbonate membranes ( $3 \mu \mathrm{m}$ holes; Nucleopore, Pleasanton, California, USA). During the critical point drying process some of the cells detached from the membranes; this happened more frequently and to a greater extent with PMN preparations from patients with RA than it did with those from normal individuals. Examination of the detached cells recovered from the drying boat showed that they occurred mainly in clumps; very few individual cells were present. When samples were examined by SEM the morphology of about 40 widely separated cells (i.e., those not forming part of a clump or aggregate) was usually studied (see text).

The details that were recorded during these observations changed in the light of experience during the course of these studies. For most samples, however, the shape and dimensions of each cell, together with an estimate of the percentage of the visible surface that was covered by each different type of surface structure, were noted, either directly from the viewing screen at magnifications of be- tween $\times 8000$ and $\times 12000$ or later from photographs taken at similar magnifications.

\section{Results}

NORMAL PMNS

A total of 20 peripheral blood PMN preparations from six normal individuals (four men, two women) whose ages ranged from 18 years to 50 years was examined by SEM. The preparations were little contaminated by other blood cells. When erythrocytes were present they appeared either circular and biconcave or echinoid; platelets appeared biconvex, smooth surfaced, and for the most part were devoid of filopodial projections. At low magnifications $(\times 100$ to $\times 1000)$ most cells were observed to be well spaced from each other, but a small proportion occurred in groups of two, three, or four cells (Fig. 1). In all of the preparations examined the majority of PMNs were apolar spherical cells with their surfaces completely covered by plasma membrane elaborated into irregular ridges or small ruffles (Figs 2a-f). Most preparations contained some cells that were slightly polarised; the spherical portion of these cells, approximately $75-95 \%$ of the visible surface area, was covered by irregular ridges or small ruffles, while the remainder was elaborated into medium sized ruffles which formed a small pseudopodial projection (Figs $2 \mathrm{~g}$ and $\mathrm{h}$ ). A small number of more highly polarised cells with ruffled pseudopodial projections comprising more than $25 \%$ of the surface were found in a few preparations (Figs 2i-1). In one preparation a small proportion of the spherical cells had their surface covered mainly by small bulges (not illustrated, but essentially similar cells can be seen in Figs $5 e$ and f). A quantitative assessment of the cell shape and surface features found in preparations of normal PMNs is presented in Table 1.

Four of the PMN preparations which had been viewed by SEM were also examined by TEM. Those preparations which by SEM were found to contain high proportions of apolar cells were seen by TEM to comprise mostly cells with circular outlines with occasional small projections at the periphery. The cytoplasm of these cells generally appeared to be in a well ordered state; it contained few phagocytic vacuoles, large numbers of undischarged electron dense granules, and the usual internal organelles such as ribosomes, endoplasmic reticulum, Golgi body, one or two mitochondria, and large numbers of glycogen granules (Fig. 6a). PMNs with irregular outlines and convoluted projections of the plasma membrane at one end of the cell were observed by TEM in those preparations which had been found by SEM to contain polarised cells. The cytoplasm 
beneath these pseudopodial projections usually contained few organelles. Highly polarised cells with extensive pseudopodial projections frequently contained more phagocytic vacuoles and fewer electron

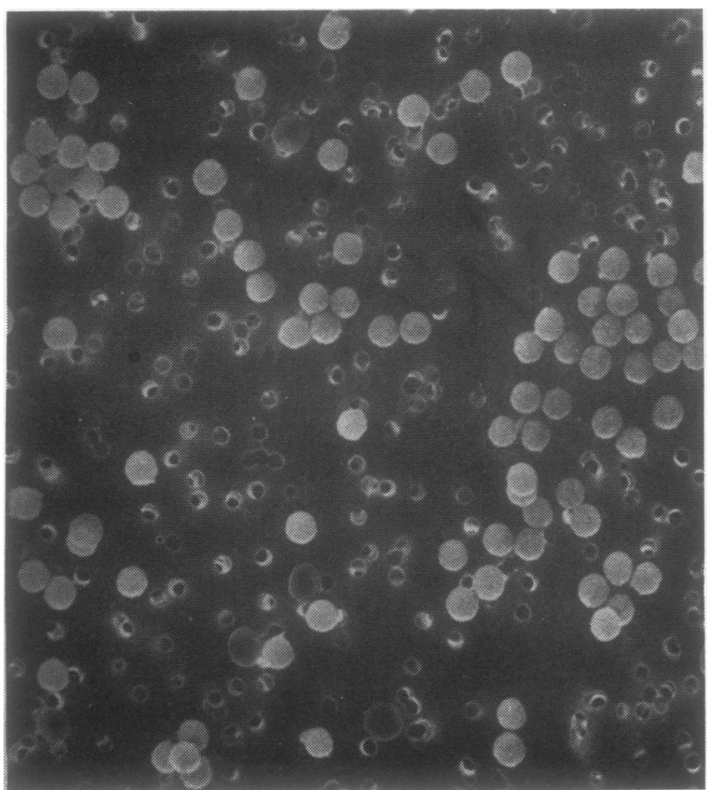

Fig. 1 Scanning electron micrograph of PMNs from a normal individual (subject No 1). dense granules than apolar spherical cells, but their cytoplasm was still well ordered (not illustrated).

RHEUMATOID ARTHRITIS PMNS

A total of 33 preparations of peripheral blood PMNs and three of synovial fluid PMNs was made from patients whose ages ranged from 27 years to 78 years. Blood samples were obtained on two different occasions from four patients; a synovial fluid sample and a blood sample were obtained at the same time from one patient. Preparations of RA peripheral blood PMNs made using Ficoll-Hypaque medium 2, and which had not been filtered, were seen by SEM at low magnifications to contain many aggregated cells (Fig. 3). Some preparations were contaminated by substantial numbers of erythrocytes and platelets. Aggregates, which contained from approximately five to 50 cells, almost always comprised a mixture of PMNs, erythrocytes, and platelets; often the cells were entwined with a thread-like material, possibly fibrin. Platelets in these preparations frequently showed evidence of having been activated, their long filopodia sometimes stretching out over the surface of neighbouring PMNs or erythrocytes. Filtering had little effect on the cell distribution in these preparations excepd to decrease the number of larger cell aggregatess Preparations of peripheral blood PMNs made using $\bar{g}$ Ficoll-Hypaque medium 3 were not filtered at any stage. They contained few aggregated cells and were

Table 1 Characteristics of the peripheral blood PMNs isolated from control subjects

\begin{tabular}{|c|c|c|c|c|c|c|c|c|c|c|c|}
\hline \multicolumn{4}{|c|}{ Subjects and sample data } & \multicolumn{8}{|c|}{ Characteristics of PMNs as seen by SEM } \\
\hline \multirow[t]{2}{*}{ Subject } & \multirow{2}{*}{$\begin{array}{l}\text { Age } \\
\text { (years) }\end{array}$} & \multirow[t]{2}{*}{ Sex } & \multirow[t]{2}{*}{ Remarks* } & \multirow{2}{*}{$\begin{array}{l}\text { Number } \\
\text { of cells } \\
\text { examined }\end{array}$} & \multicolumn{4}{|c|}{ Cell shape $(\%) \dagger$} & \multicolumn{3}{|c|}{ Surface membrane structure $(\%)$} \\
\hline & & & & & Apolar & $\begin{array}{l}\text { Slightly } \\
\text { polar }\end{array}$ & $\begin{array}{l}\text { Highly } \\
\text { polar }\end{array}$ & Spherical & Ridges & Ruffles & Smooth \\
\hline 1 & 41 & $\mathbf{M}$ & & 183 & 99 & 1 & & & 99 & 1 & \\
\hline 1 & 42 & $\mathbf{M}$ & & 78 & 92 & 6 & 1 & & 99 & 1 & \\
\hline 1 & 42 & $\mathbf{M}$ & $150 \mathrm{~min}$ & 50 & 95 & 5 & & & 99 & 1 & \\
\hline 1 & 42 & M & $120 \mathrm{~min}$ & 20 & 98 & 1 & 1 & & 95 & 5 & \\
\hline 1 & 42 & $\mathbf{M}$ & & 79 & 77 & 20 & 3 & & & Not done & \\
\hline 1 & 42 & $\mathbf{M}$ & & 48 & 65 & 35 & & & 82 & 16 & \\
\hline 1 & 43 & $\mathbf{M}$ & & 26 & 60 & 20 & & & 87 & 14 & \\
\hline 1 & 43 & $\mathbf{M}$ & & 46 & 65 & 20 & 5 & 10 & 53 & 38 & 9 \\
\hline 2 & 26 & $\mathbf{F}$ & & 46 & 96 & 4 & & & 99 & 1 & \\
\hline 2 & 26 & $\mathbf{F}$ & & 50 & 68 & 30 & 2 & & & Not done & \\
\hline 2 & 27 & $\mathbf{F}$ & & 63 & 67 & 30 & 3 & & 68 & 26 & 6 \\
\hline 2 & 27 & $\mathbf{F}$ & $330 \mathrm{~min}$ & 29 & 59 & 21 & 21 & & 60 & 36 & 4 \\
\hline 3 & 21 & $F$ & & 107 & 76 & 21 & 4 & & & Not done & \\
\hline 4 & 47 & $\mathbf{M}$ & & 50 & 85 & 15 & & & 85 & 10 & 5 \\
\hline 5 & 28 & $\mathbf{M}$ & & 50 & 80 & 20 & & & 80 & 20 & \\
\hline 6 & 25 & M & & 56 & 86 & 14 & & & 84 & 13 & 3 \\
\hline
\end{tabular}

* Remarks: min=time interval in minutes between blood being taken and being centrifuged over Ficoll-Hypaque when this exceeded 15 minutes.

$†$ Terms used to describe cell shapes have been defined in the text. 
Scanning electron microscopy of polymorphonuclear leucocytes in $R A$
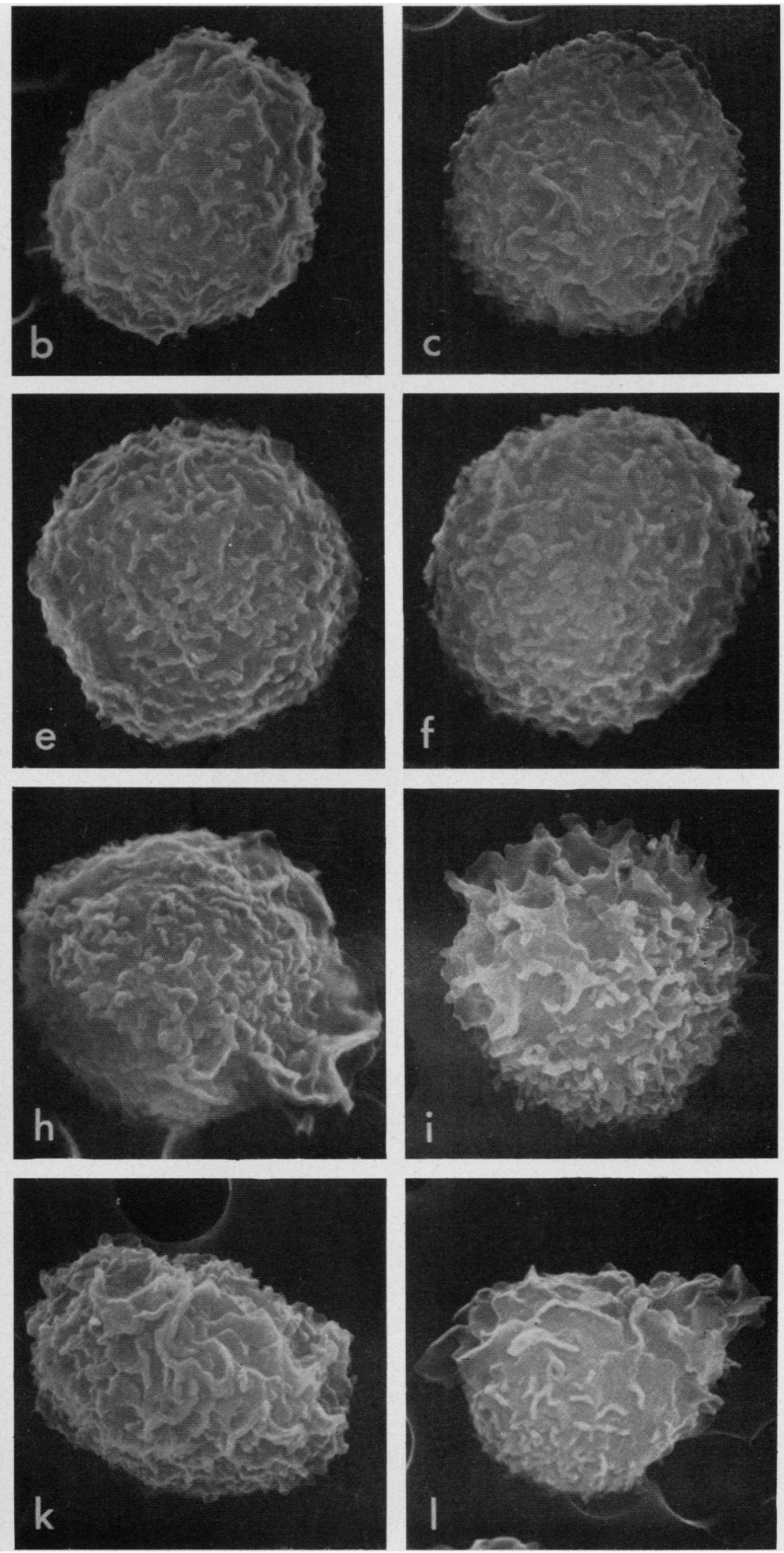

a
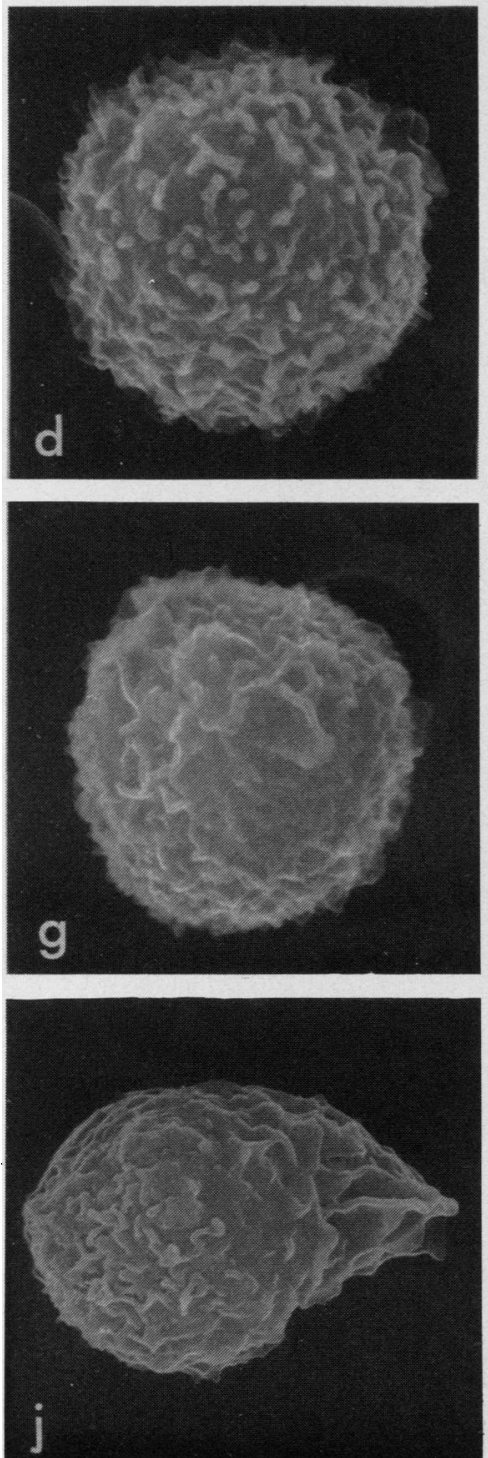

Fig. 2 Scanning electron micrographs of PMNs from normal individuals: cell(s) from subject No 1 illustrated in a, $c$, e-i, $k$, and $l$, from subject No 2 in $d$, and from subject No 6 in $b$ and $j$. The range of cell morphology illustrated in this plate is representative of that which would be found in most PMN preparations made from normal individuals. 


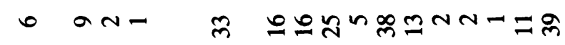

주요요 잉

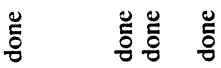

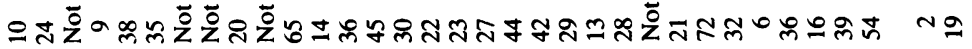

芯

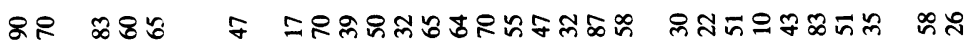

की

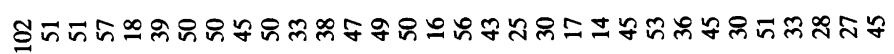

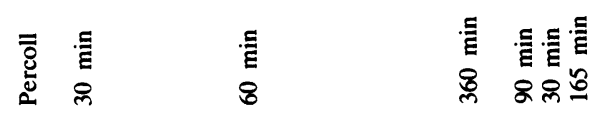

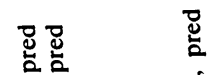

ฐ $\frac{5}{0}$

竞
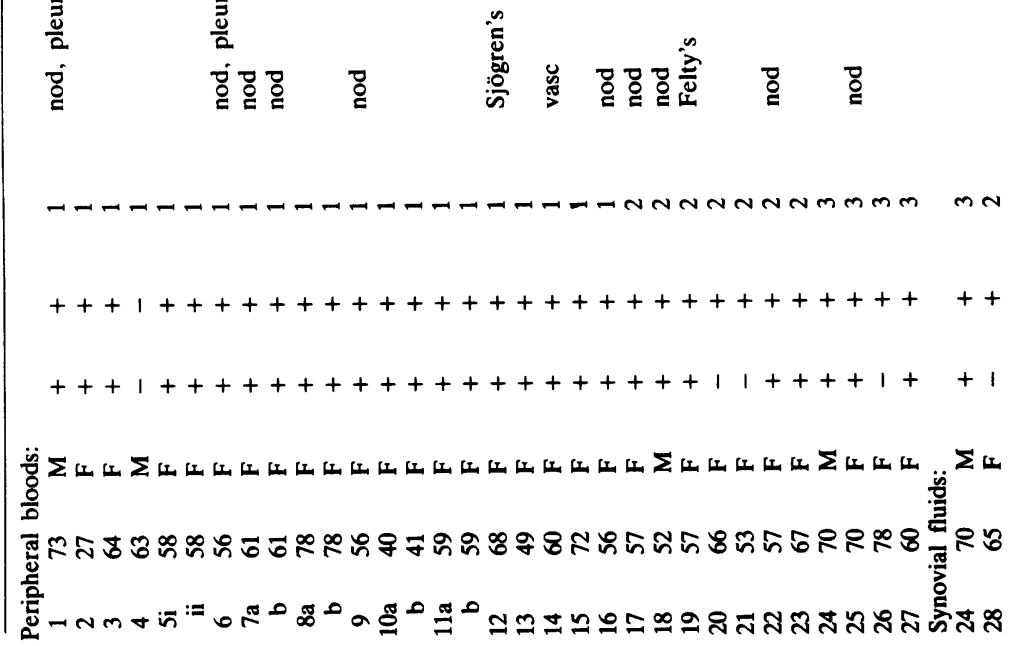

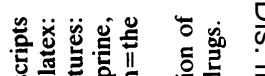

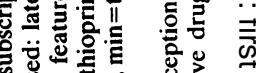

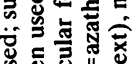

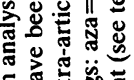

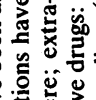

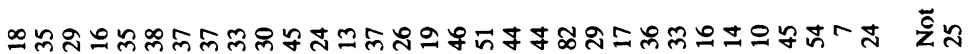

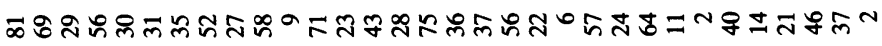




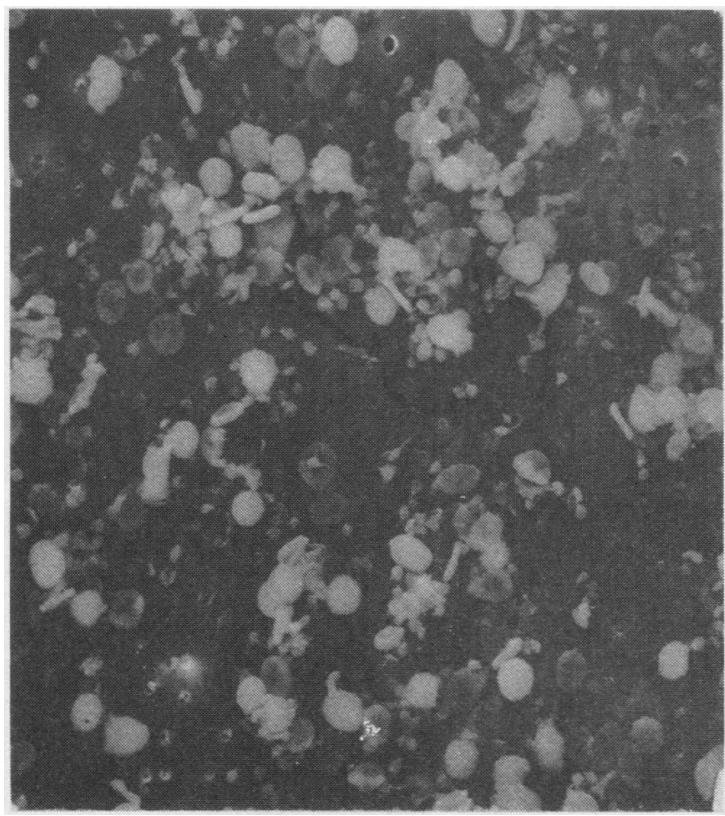

Fig. 3 Scanning electron micrograph of PMNs from a patient with RA (No 11) illustrating the appearance of samples obtained by centrifuging $R A$ bloods over Ficoll-Hypaque medium 2.

little contaminated by erythrocytes or platelets. Aggregates in preparations made using medium 3 usually comprised from approximately three to 10 cells, and, although platelets and erythrocytes were sometimes present as well as PMNs, they mostly contained just PMNs (not illustrated). Although the morphology of cells in an aggregate was not studied in detail, we formed the distinct impression that aggregated cells were more often polarised than were unaggregated cells.

The peripheral blood PMNs from many patients with RA showed a range of morphological variations similar to that seen in preparations made from bloods of normal subjects (Figs 4a-f). In PMN preparations from the bloods of most patients with RA, however, the proportion of apolar cells was lower and that of polarised cells correspondingly higher than in preparations made from the bloods of normal individuals (Figs 4g-i; Figs 5a-c; Table 2). In addition, preparations from some patients with RA contained PMNs in which parts of the plasma membrane were formed into bulges and blebs (Figs $5 \mathrm{~d}-\mathrm{f}$ ), while that from another patient contained large numbers of PMNs which although spherical were covered mainly by a smooth plasma membrane in which there were occasional crater-like pits (Figs $5 \mathrm{~g}-\mathrm{l})$. Neither of these latter types of surface structure was seen in PMNs isolated from normal individuals (for simplicity these cells have been included in the 'spherical' category for the purpose of compiling Table 2).

TEM examination showed that apolar RA PMNs often contained more phagocytic vacuoles than apolar cells isolated from normal individuals (Fig. $6 \mathrm{~b})$ and that highly polarised RA PMNs contained many phagocytic vacuoles but few electron dense granules (Fig. 6c). Those RA PMNs which had plasma membrane contours consistent with the existence of bulges, blebs, and pits on their surface had cytoplasm which seemed markedly disordered (Fig. 6d)

The range of morphological variation found in the three preparations of RA synovial fluid PMNs that were examined by SEM was similar to that which was found in preparations of RA peripheral blood PMNs.

\section{Discussion}

Our observations on the morphology of normal PMNs by SEM and TEM are generally in agreement with those of others. ${ }^{25} 26$ As we are unaware of any previous quantitative analysis of PMN morphology by SEM we believe that our study provides new information on the morphological variation that might be encountered during experiments with purified PMNs. The main feature of our results, however, is that PMN preparations made from the blood of most patients with RA contained a lower proportion of apolar cells than did similar preparations made from most normal bloods (Table 3). Polarised PMNs from the bloods of both normal subjects and patients with RA when seen by SEM resembled in most respects normal PMNs that had been exposed to chemoattractants or to aggregating agents in vitro. ${ }^{1819}$ The results of our concurrent TEM observations support the suggestion that greater phagocytic (and perhaps 'frustrated' phagocytic) activity had occurred in polarised PMNs found in the preparations made from the bloods of patients with RA than had occurred in the polarised PMNs found in preparations made from normal bloods. Moreover, the ultrastructural changes seen in these cells resembled those seen to occur in normal PMNs which were phagocytosing aggregated immunoglobulins or rheumatoid factor containing complexes. ${ }^{27}{ }^{28}$ PMNs whose surfaces were seen by SEM to be covered in bulges and blebs and that were found almost exclusively in preparations made from the bloods or synovial fluids of patients with RA bore a strong resemblance to normal PMNs that had ingested large numbers of bacteria in vitro. ${ }^{29}$ 

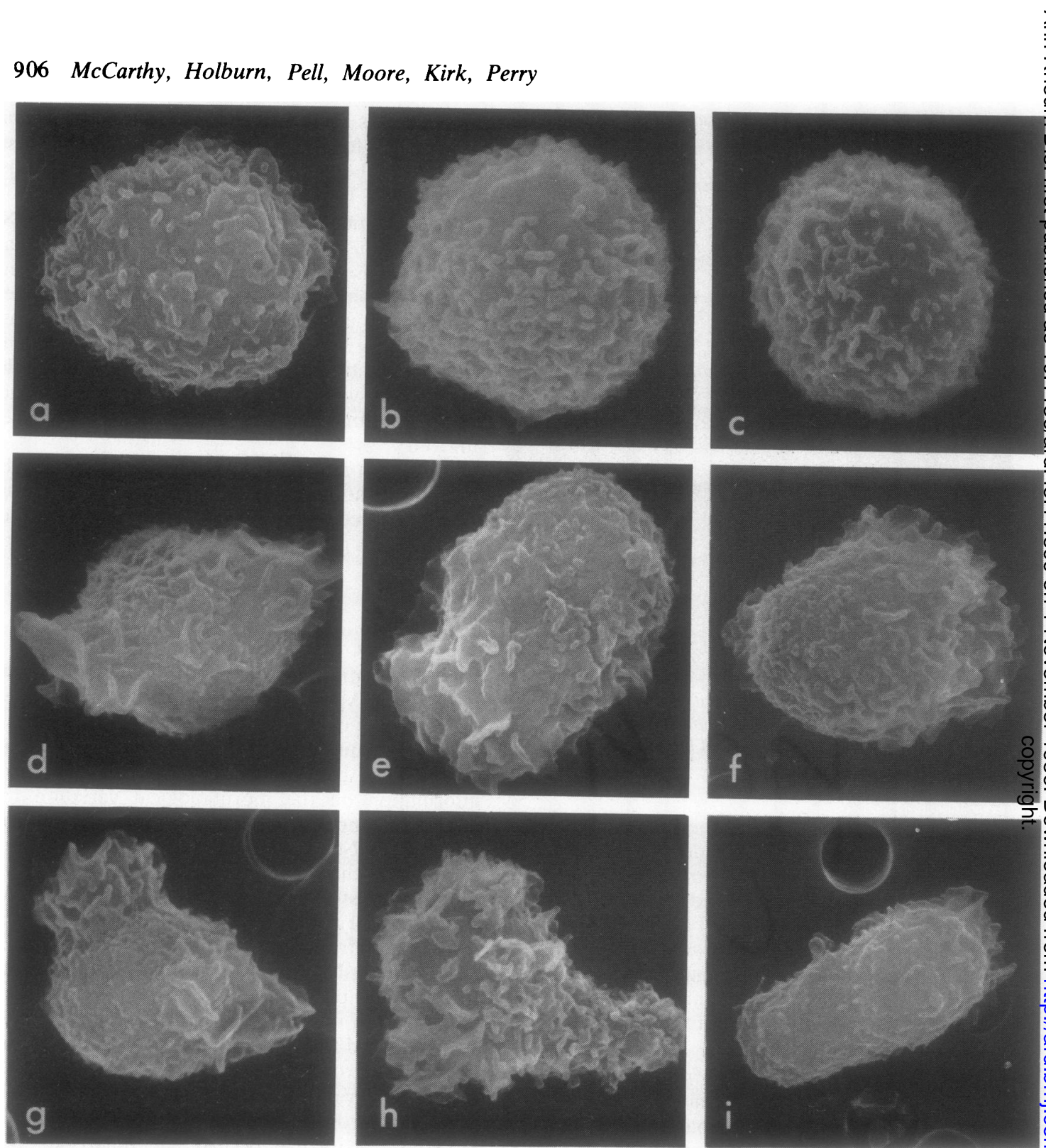

Fig. 4 Scanning electron micrographs of PMNs from patients with RA: cell(s) from patient No 5 illustrated in $b$, from patient No $8 b$ in $g$, from patient No 9 in $c$, from patient $N o l 0 b$ in $d, f, h$, and $i$, from patient No 11 a in a, and from patient No 27 in e.

An inverse correlation was found between the severity of active inflammatory disease (activity index 1 versus activity index 2 plus 3 ) and the proportion of apolar PMNs that occurred in preparations made from bloods of patients with RA (Fig. 7). Unfortunately it was not possible to deduce what effects drug therapy might have had on PMN morphology because the patient numbers in each category were too low.
A crucial question raised by these results is the extent to which the morphology and ultrastructure of PMNs might change between the blood being drawn from the circulation and the purified cells being fixed for microscopy. In this respect we would contend that, except where otherwise stated, circulating PMNs were separated from other blood components and purified as rapidly as present techniques allow, and that they were fixed by a 

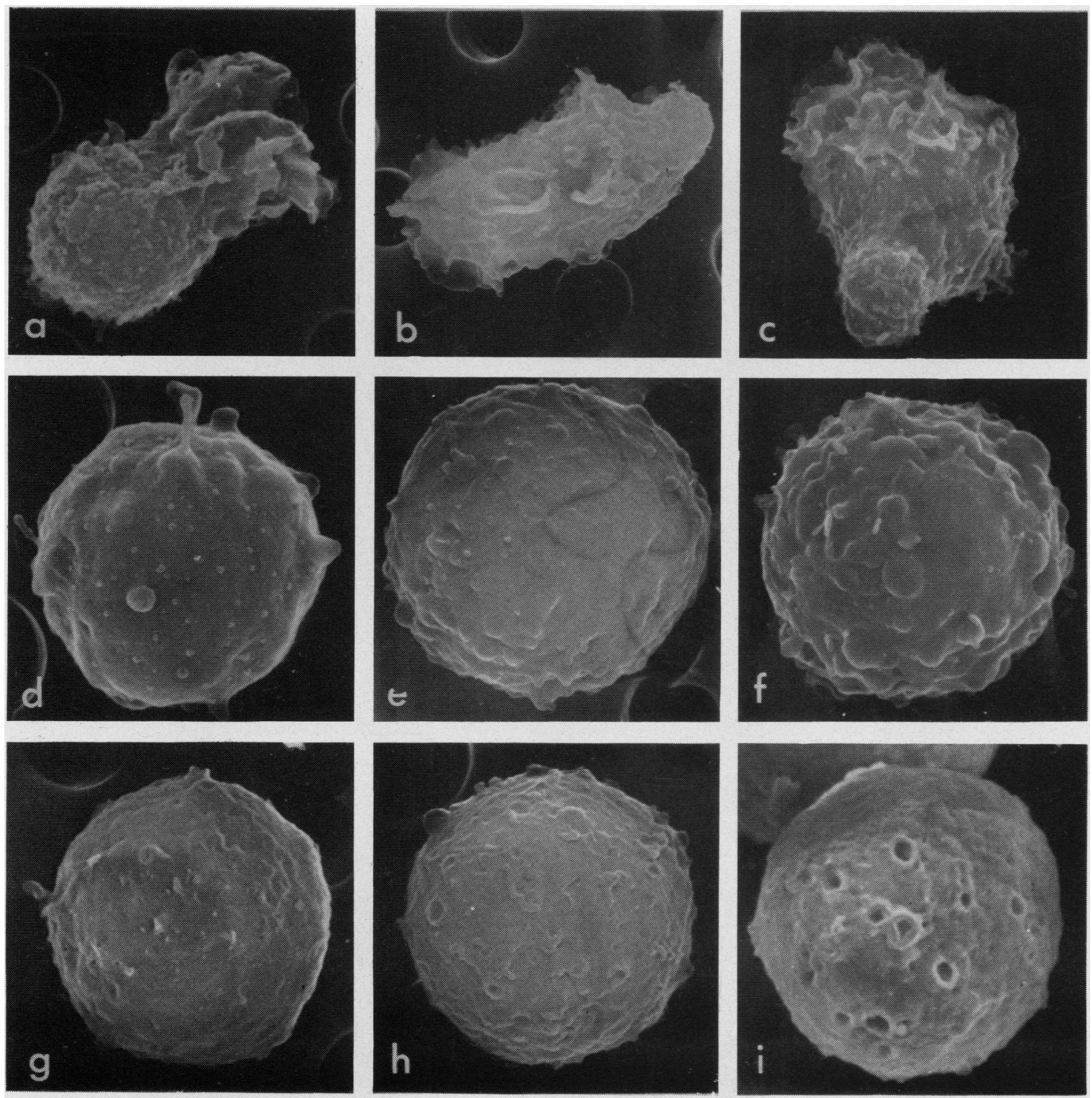

Fig. 5 Scanning electron micrographs of PMNs from patients with $R A$ : cell(s) from patient No $7 b$ illustrated in $d, e$, and $f$, from patient $N o 8 b$ in a and $b$, from patient No $10 b$ in $c$, and from patient $N o 24$ in $g, h$, and $i$.

procedure that is unlikely to cause selectively artefactual changes in RA PMNs. Accordingly we would suggest that polarised PMNs represent cells which have come into contact with $\mathrm{C} 5 \mathrm{a}$ or other chemotactic factors while suspended in the circulation or which have returned recently from the marginated granulocyte pool to the circulating pool, or both, but that have not yet resumed a spherical shape. For it is known that in man the two pools which are of about equal size are in constant equilibrium, ${ }^{2}$ and that marginated PMNs which have 'settled' on the luminal surface of veins develop ruffled lamellipodia. ${ }^{30}$ Conversely, if it is assumed that all of the PMNs which circulate in both normal individuals and in patients with RA are spherical and unpolarised then it must be concluded that there are factors present in many RA bloods but which are largely absent from normal bloods 
908 McCarthy, Holburn, Pell, Moore, Kirk, Perry

that can cause PMNs to become polarised in vitro during the isolation procedure. Immune complexes and activated complement components are substances which could act in this way. Further studies,

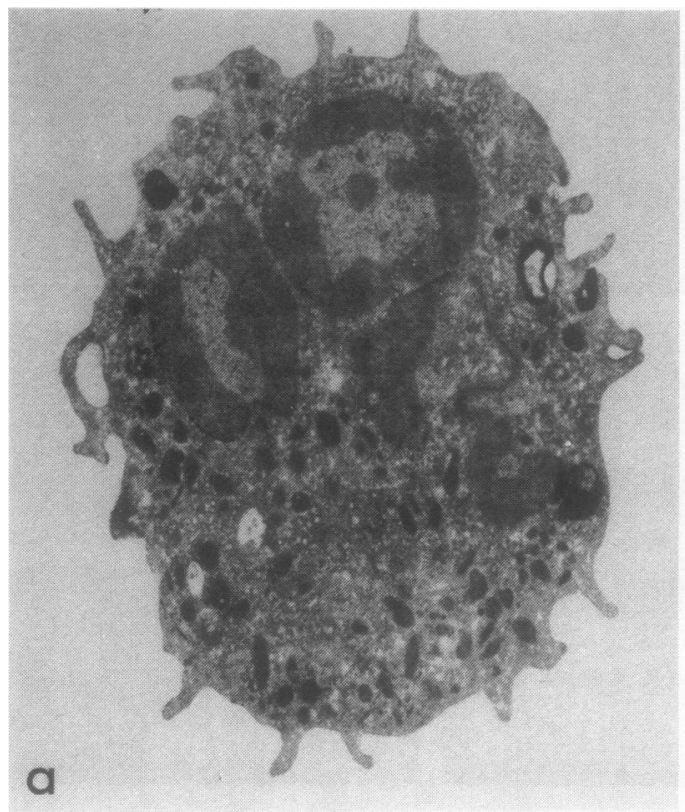

perhaps using different techniques, are needed clarify this point. The same criticisms can of cour be made of the vast majority of experiments in which purified PMNs have been used, e.g., fo्p
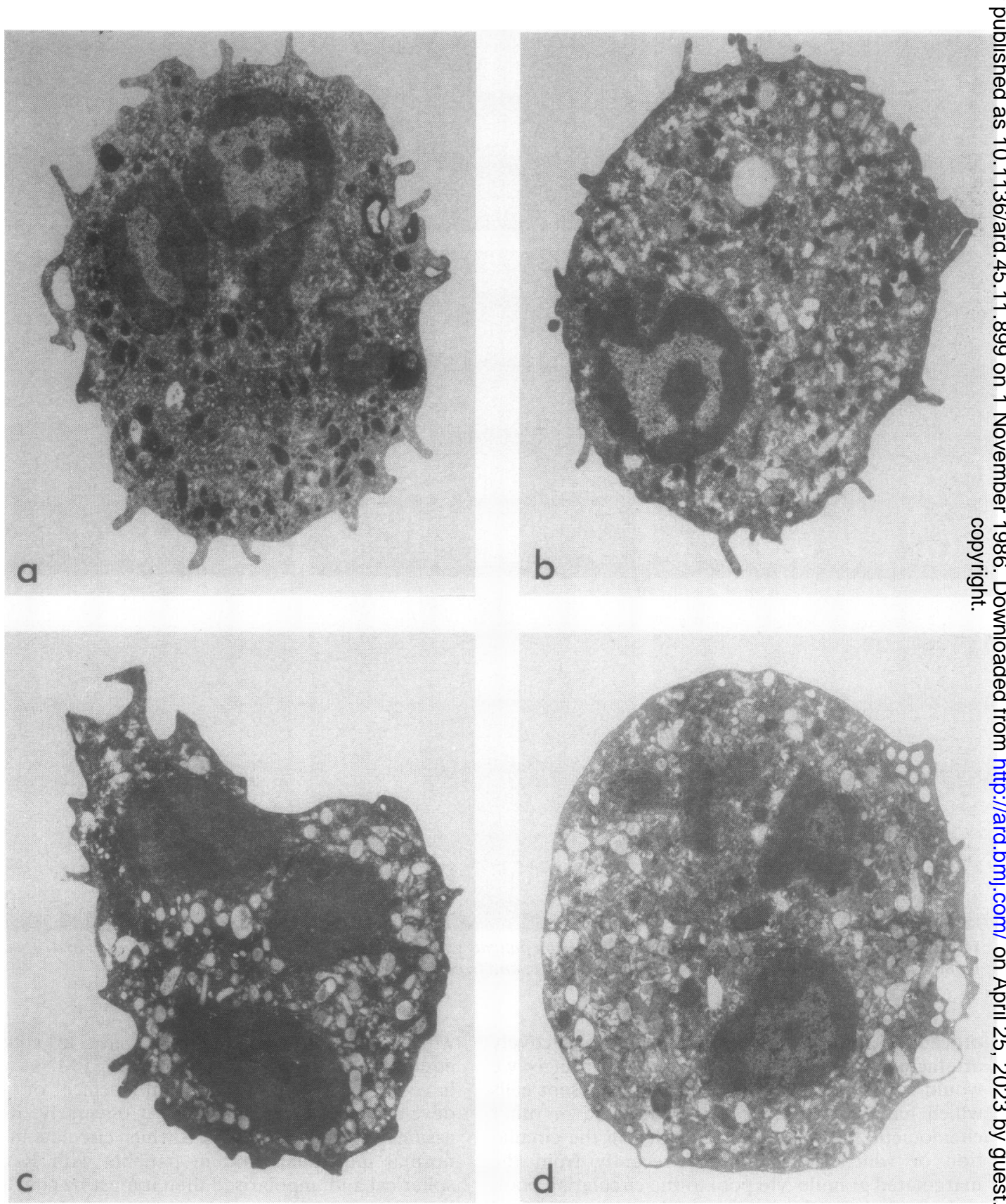

Fig. 6 Transmission electron micrographs of PMNs from a subject No $I$ (a) and from patients with RA Nos 25, IIa, and 0 24 ( $b, c$, and $d$, respectively). 
Table 3 Comparative summary of the characteristics of the peripheral blood PMNs isolated from patients with rheumatoid arthritis and from control subjects*

\begin{tabular}{|c|c|c|c|c|c|c|c|}
\hline \multirow[t]{3}{*}{ Group } & \multicolumn{7}{|c|}{ Characteristics of PMNs as seen by SEM } \\
\hline & \multicolumn{4}{|c|}{ Cell shape (\%) } & \multicolumn{3}{|c|}{ Surface membrane structure (\%) } \\
\hline & Apolar & $\begin{array}{l}\text { Slightly } \\
\text { apolar }\end{array}$ & $\begin{array}{l}\text { Highly } \\
\text { apolar }\end{array}$ & Spherical & Ridges & Ruffles & Smooth \\
\hline $\begin{array}{l}\text { Rheumatoid arthritis } \\
\text { Normal controls }\end{array}$ & $\begin{array}{l}40(5) \\
78(7)\end{array}$ & $\begin{array}{l}31(5) \\
18(5)\end{array}$ & $\begin{aligned} 25(8) \\
2(1)\end{aligned}$ & $\begin{array}{l}6(5) \\
1(1)\end{array}$ & $\begin{array}{l}55(9) \\
84(9)\end{array}$ & $\begin{array}{l}31(7) \\
14(7)\end{array}$ & $\begin{aligned} 13(8) \\
2(2)\end{aligned}$ \\
\hline
\end{tabular}

*Values are mean (2 SEM); they do not always total $100 \%$ because of accumulated errors in rounding up or down. Data taken from Tables 1 and 2 except that samples aged in vitro have been omitted.

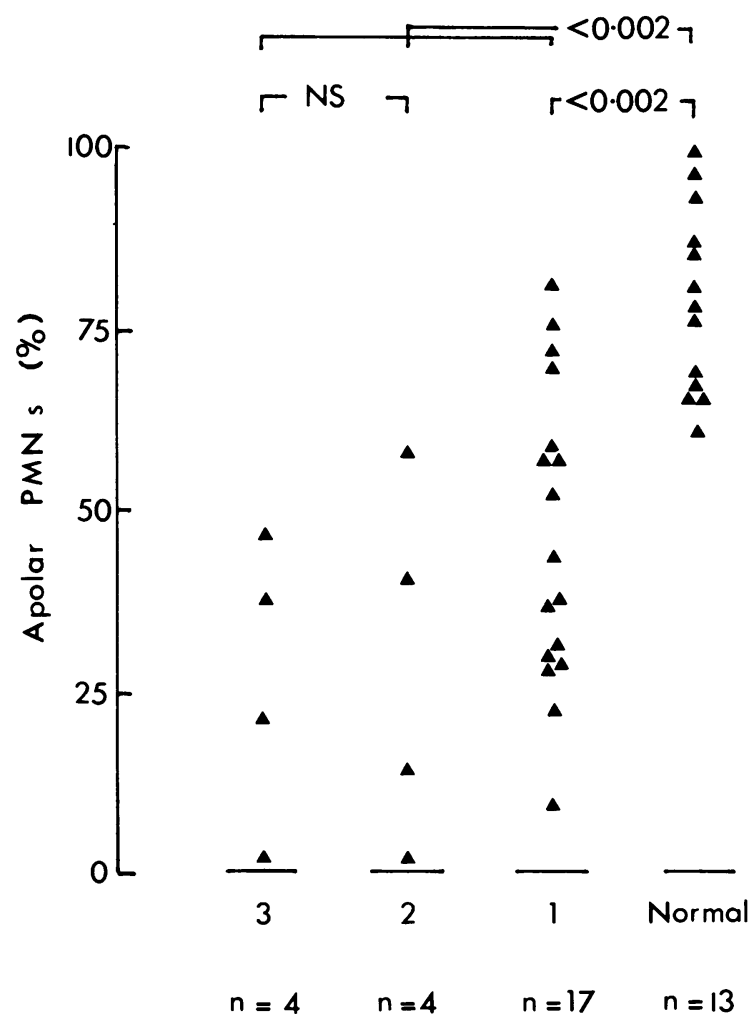

Activity index

Fig. 7 The percentage of apolar cells found in peripheral blood PMN preparations made from normal individuals and from patients categorised according to their current disease activity. Wilcoxon's rank sum test was used to calculate the probability that the differences were not significant; $N S=$ not significant. Data taken from Tables 1 and 2 except that samples aged in vitro have been omitted. measurements of electrophoretic mobility or for assays of functional activity. Thus our observations may provide a morphological correlation to those investigations in which differences in biochemical properties or in biological activities have been shown within populations of normal $\mathrm{PMNs}^{31}$ or between RA and normal PMNs (vide supra).

We are grateful to the Arthritis and Rheumatism Council for financial assistance; to all persons who gave blood for use in this study; to Mr R Stow, Miss N Ibrahim, and Miss J Shreeve for help with some of the experiments; to the staff of the Rheumatology Department (London Hospital) and of the Medical Centre (Queen Mary College) for assistance in collecting bloods; to Drs $R$ Melsom, M Field, and K A Brown for valuable discussions; to Prof E J Holborrow for his encouragement; and to Sterling Research Laboratories for supplying diatrizoate salts. We apologise for the omission of many references to significant and relevant papers because of space limitations; in most instances these are listed in the papers which we have cited.

\section{References}

1 Prior P, Symmons D P M, Scott D L, Brown R, Hawkins C F. Cause of death in rheumatoid arthritis. Br J Rheumatol 1984; 23: 92-9.

2 Wintrobe M M, Lee G R, Bogg D R, et al. Clinical haematology. 8th ed. Philadelphia, USA: Lea and Febiger, 1981.

3 Elmgreen J, Hansen T M. Subnormal sensitivity of neutrophils to complement split product $\mathrm{C5a}$ in rheumatoid arthritis: relation to complement catabolism and disease extent. Ann Rheum Dis 1985; 44: 514-8.

4 Attia W M, Shams A H, Ali M K, Clark H W, Brown T M, Bellanti J A. Studies of phagocytic cell function in rheumatoid arthritis I. Phagocytic and metabolic activities of neutrophils. Ann Allergy 1982; 48: 279-82.

5 Bultmann B, Geitner R, Siebold H, Kratsch G, Haferkamp O. Interaction of circulating immune complexes with granulocyte function in patients with rheumatoid arthritis. Klin Wochenschr 1980; 58: 727-32.

6 Okuda K, Tadokoro I, Noguchi Y. Nitroblue tetrazolium (NBT)-dye test and the myeloperoxidase reaction of human leukocytes. Jpn J Microbiol 1975; 18: 337-42.

7 Howe G B, Fordham J N, Brown K A, Currey H L F. Polymorphonuclear cell function in rheumatoid arthritis and Felty's syndrome. Ann Rheum Dis 1981; 40: 371-5.

8 Shehan $\mathbf{N ~ J , ~ B r o w n ~ K ~ A , ~ D u m o n d e ~ D ~ C . ~ A ~ r a d i o m e t r i c ~}$ assessment of phagocytosis and intracellular killing by blood 
polymorphonuclear leucocytes in rheumatoid arthritis. $\mathrm{Br} J$ Rheumatol 1984; 23: 193-202.

9 Breedveld F C, van den Barselaar M T, Leijh P C J, Cats A, van Furth $R$. Phagocytosis and intracellular killing by polymorphonuclear cells from patients with rheumatoid arthritis and Felty's syndrome. Arthritis Rheum 1985; 28: 395-404.

10 Spisani S, Marangoni C, Dovigo L, Traniello S. The effect of anti-inflammatory agents on neutrophil superoxide production in rheumatoid arthritis. Inflammation 1984; 8: 45-50.

11 Breedveld F C, Lafeber G J M, De Vries E, Leijh P N J, Daha M R, Cats A. Fc receptors on granulocytes from patients with rheumatoid arthritis and Felty's syndrome. Clin Exp Immunol 1984; 55: 677-83.

12 Cats A, Lafeber G J M, Klein F. Immunoglobulin phagocytosis by granulocytes from sera and synovial fluid in various rheumatoid and non-rheumatoid diseases. Ann Rheum Dis 1975; 34: 146-55.

13 Brown K A, Goddard D H, Fordham J F, Currey H L F, Holborrow E J. Polymorphonuclear (PMN) cell function in rheumatoid arthritis (RA) is related to surface charge. In: Preece A W, Light P A, eds. Cell electrophoresis in cancer and other clinical research. Amsterdam: Elsevier/North Holland, 1981: 209-16.

14 Breedveld F C, Lafeber G J M, De Vries E, Daha M R, Cats A. $\mathrm{C}_{3}$ receptors on granulocytes from patients with rheumatoid arthritis and Felty's syndrome. Clin Exp Immunol 1984; 57: 557-63.

15 Spisani S, Manservigi R, Dovigo L, Albonici L, Traniello S. Defective expression of neutrophil membrane proteins in patients with rheumatoid arthritis. J Clin Lab Immunol 1985; 16: 77-9.

16 Gallin J I. Degranulating stimuli decrease the negative surface charge and increase the adhesiveness of neutrophils. $J$ Clin Invest 1980; 65: 298-306.

17 Smith C W, Hollers J C, Patrick R A, Hussett C. Motility and adhesiveness in human neutrophils: Effects of chemotactic factors J Clin Invest 1979; 63: 221-9.

18 Craddock P R, Hammerschmidt D, White J G, Dalmasso A P, Jacob H S. Complement (C5a)-induced granulocyte aggregation in vitro. J Clin Invest 1977; 60: 260-4.

19 Yuli I, Synderman R. Rapid changes in light scattering from human polymorphonuclear leucocytes exposed to chemoattractants: discrete responses correlated with chemotactic and secretory functions. J Clin Invest 1984; 73: 1408-17.
20 Ferrante $A$, Thong $Y H$. A rapid one-step procedure for purification of mononuclear and polymorphonuclear leucocytes from human blood using a modification of the Hypaque-Ficoll? technique. J Immunol Methods 1978; 24: 389-93.

21 Ferrante A, James D W. Betts W M. Cleland L G. Rapid $\overrightarrow{\vec{S}}$ single-step method for purification of polymorphonuclear leuco-O cytes from blood of patients with rheumatoid arthritis. Clin Exp Immunol 1982; 47: 749-52.

22 McCarthy D A. Perry J D. Holburn C M, et al. Centrifugation of normal and rheumatoid arthritis blood on Ficoll-Hypaque and Ficoll-Nycodenz solutions. J Immunol Methods 1984: 73:ه 415-25.

23 Pertoft $\mathrm{H}$, Hirtenstein M, Kagedal L. Cell separations in a new $\overrightarrow{0}$ density medium. Percoll R. In: Reid E, ed. Cell populations, methodological surveys (B) Biochemistry. Vol 9. Chichester UK: Ellis Hopwood Ltd, 1979: 67-80.

24 McCarthy D A. Pell B K. Holburn C M, et al. A tannic acidd based preparation procedure which enables leucocytes to be으 examined subsequently by cither SEM or TEM. J Microsc 1985 ; 137: 57-64.

25 Baggiolini M, Dewald B. The neutrophil. Int Arch Allergy ApplImmunol 1985; 76(suppl 1): 13-20.

26 Haston W S. Shiclds J M. Neutrophil leucocyte chemotaxis: ace simplified assay for measuring polarising responses to chemo-o tactic factors. J Immunol Methods 1985; 81: 229-38.

27 Weissman G, Zurier R B. Hoffstein S. Leukocytic proteasesand the immunologic release of lysosomal enzymes. Am JO Pathol 1972; 68: 539-64.

28 Henson P M. Mechanism of release of granule enzymes from human neutrophils phagocytosing aggregated immunoglobulin. An electron microscopic study. Arthritis Rheum 1973; 16:208-16.

29 MacRae E K. Pryzwansky K B, Cooney M H, Spitznagel 迎. Scanning electron microscopic observations of early stages 7 or phagocytosis of E coli by human neutrophils. Cell Tissue 1980; 209: 65-70.

30 Stewart G J, Lynch P R. Reichle F A, Ritchie W G M, Smith A Schaub R G. The adhesion of leukocytes, crythrocytes and non cellular material to the luminal surface of natural and artificiap blood vessels in vivo. Ann N Y Acad Sci 1977; 283: 179-207. Q

31 Stavem P, Dahl O. Differences in phagocytic/adherence prop $\vec{B}$ erties between normal neutrophils. Scand J Haematol 1984; 33: $212-4$

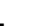

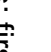

